\title{
Correction to: Elbow flexion reconstruction after arm-sparing excision for high-grade triton sarcoma: a case report
}

Elise Lupon ${ }^{1,2^{*}}$, Christine Chevreau ${ }^{3}$, Alexandre Gaston Lellouch ${ }^{2,4}$, Dimitry Gangloff ${ }^{1,5}$ and Thomas Meresse ${ }^{1,5}$

Correction to: J Med Case Reports 14, 103 (2020)

https://doi.org/10.1186/s13256-020-02384-y

Following publication of the original article [1], the authors identified an error in the author name of Alexandre Gaston Lellouch.

The incorrect author name is: Alexandre Lellouch

The correct author name is: Alexandre Gaston Lellouch

The author group has been updated above and the original article [1] has been corrected.

\begin{abstract}
Author details
${ }^{1}$ Department of Plastic surgery, University Toulouse III Paul Sabatier,

Toulouse, France. ${ }^{2}$ Vascularized Composite Allotransplantation Laboratory, Center for Transplantation Sciences, Massachusetts General Hospital, Harvard Medical School, 55 Blossom Street, Boston, MA 02114, USA. ${ }^{3}$ Medical Oncology, Comprehensive Cancer Center, Claudius Regaud Institute, Institut Universitaire du Cancer de Toulouse Oncopole, 1, avenue Irène Joliot-Curie, 31059 Toulouse, France. ${ }^{4}$ Department of Plastic Surgery, European George Pompidou Hospital, University of Paris, Paris, France. ${ }^{5}$ Department of Plastic Surgery, Institut Universitaire du Cancer de Toulouse Oncopole, Institut Claudius Regaud, 1, avenue Irène Joliot-Curie, 31059 Toulouse, France.
\end{abstract}

Published online: 07 August 2020

\section{Reference}

1. Lupon E, Chevreau C, Lellouch A, et al. Elbow flexion reconstruction after arm-sparing excision for high-grade triton sarcoma: a case report. J Med Case Rep. 2020;14:103. https://doi.org/10.1186/s13256-020-02384-y.

\footnotetext{
The original article can be found online at https://doi.org/10.1186/s13256020-02384-y.

* Correspondence: elupon@mgh.harvard.edu

'Department of Plastic surgery, University Toulouse III Paul Sabatier,

Toulouse, France

${ }^{2}$ Vascularized Composite Allotransplantation Laboratory, Center for

Transplantation Sciences, Massachusetts General Hospital, Harvard Medical

School, 55 Blossom Street, Boston, MA 02114, USA

Full list of author information is available at the end of the article
}

(c) The Author(s). 2020 Open Access This article is licensed under a Creative Commons Attribution 4.0 International License, which permits use, sharing, adaptation, distribution and reproduction in any medium or format, as long as you give appropriate credit to the original author(s) and the source, provide a link to the Creative Commons licence, and indicate if changes were made. The images or other third party material in this article are included in the article's Creative Commons licence, unless indicated otherwise in a credit line to the material. If material is not included in the article's Creative Commons licence and your intended use is not permitted by statutory regulation or exceeds the permitted use, you will need to obtain permission directly from the copyright holder. To view a copy of this licence, visit http://creativecommons.org/licenses/by/4.0/ The Creative Commons Public Domain Dedication waiver (http://creativecommons.org/publicdomain/zero/1.0/) applies to the data made available in this article, unless otherwise stated in a credit line to the data. 